University of Louisville

ThinkIR: The University of Louisville's Institutional Repository

Electronic Theses and Dissertations

1940

\title{
The effect of annealing on Neumann bands.
}

Alex B. Davidson

University of Louisville

Follow this and additional works at: https://ir.library.louisville.edu/etd

Part of the Chemical Engineering Commons

\section{Recommended Citation}

Davidson, Alex B., "The effect of annealing on Neumann bands." (1940). Electronic Theses and Dissertations. Paper 1705.

https://doi.org/10.18297/etd/1705

This Master's Thesis is brought to you for free and open access by ThinkIR: The University of Louisville's Institutional Repository. It has been accepted for inclusion in Electronic Theses and Dissertations by an authorized administrator of ThinkIR: The University of Louisville's Institutional Repository. This title appears here courtesy of the author, who has retained all other copyrights. For more information, please contact thinkir@louisville.edu. 


\title{
UHIVEASITY OP LOUISVILER
}

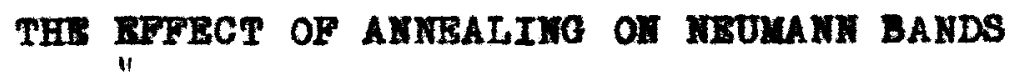

\author{
A Thesis \\ Subuitted to the Proulty \\ of the Graduate sehool \\ of the University of Lou1sville \\ 1 Partial Pulfillment \\ of the Requirementa \\ for the Degree of
}

UASTHA OF CHEUICAL BMOIABMRINO

Depertment of Chomieal Ingineering

\author{
Alex B $\hat{D}_{n}^{0}$ \\ 1940
}


TEE EFEECT OF ANNEALIMO ON NRUMANA BANDS

\author{
Alex B.Dar1dsen
}

Approved by the Bxamining Comitte.

Director

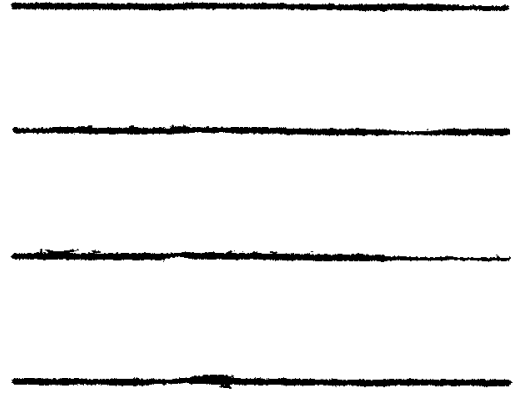

Kay 22,1940 
CONTREYTs

Pago

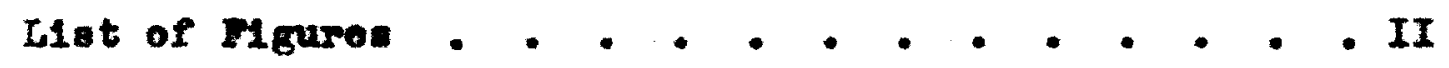

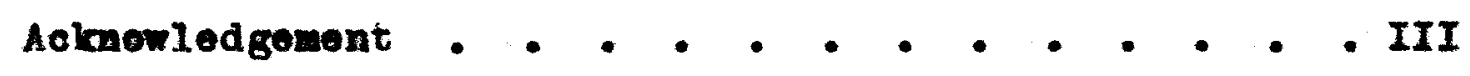
Abstract - . . . . . . . - . . . - . . IV

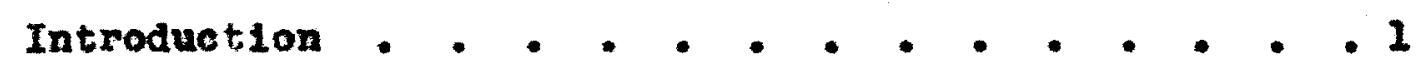
Hietorierl . . . . . . . . . . . . . . . 3 Thooreticel . . . . . . . . . . . . . 6 Apparatus - . . . . . . . . . . . . . . 11 Procedure . . . . . . . . . . . . . . 14 Dete and Results. . . . . . . . . . . . . 17

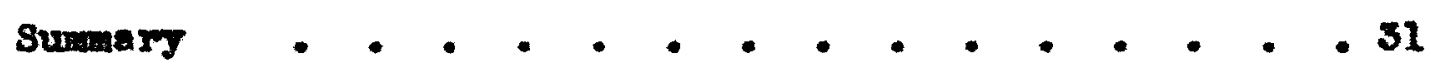
Append1x . . . . . . . . . . . . . . 33 I1terature C1ted. + . . . . . . . . . . 35

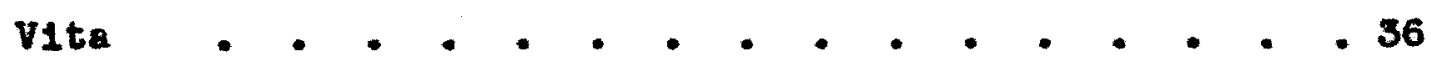




\section{LIST OF FIOURES}

Page

P1gure 1. The Iron - Iron Carbon Bquilibrium Diagran 10 P1gare 2. Affect of 1 hour Anneal at 950 degrees $C . \quad 19$

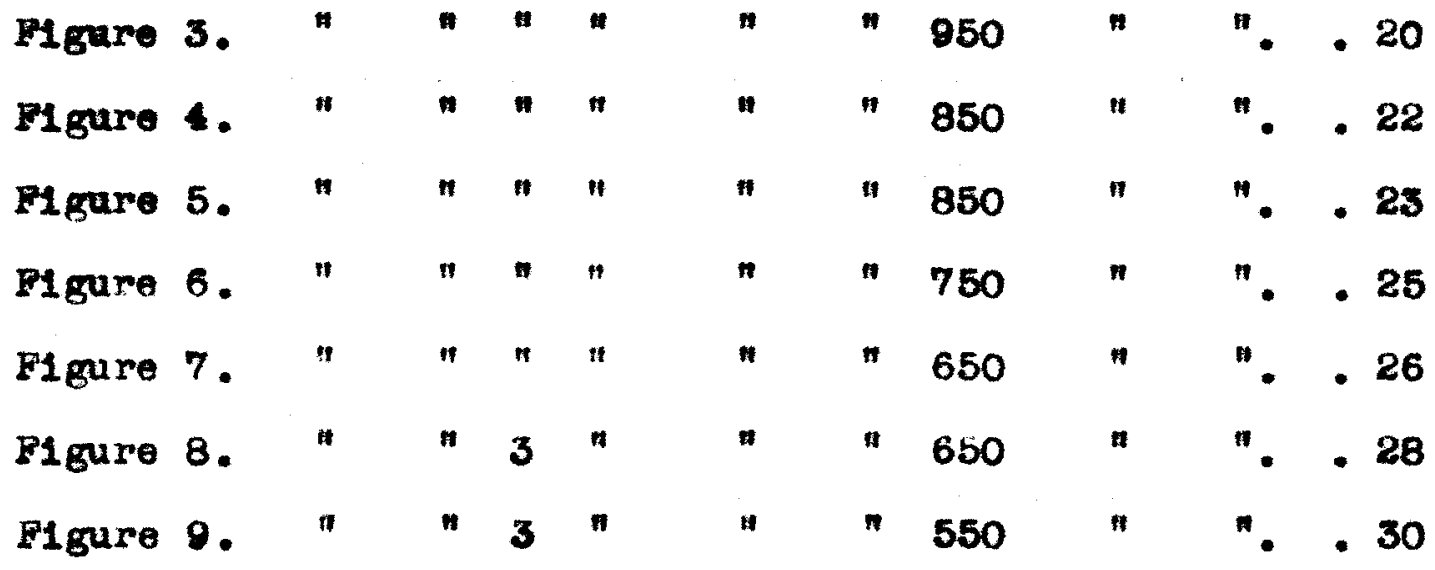




\section{ACKMORLEDOEMENT}

The author wiahes to acknowledge the

kind assistance and heloful guidanee

of Dr.a.C. W1111ans, who

directed this revearoh. 


\section{ABSTRACT}

The oxact structure of Meumann bends is controversial, and there 1s some doubt a to thoir behavior under different conditions. Th1s thesis 1s an Investigation of the action of Meurann bands, under different annealing conditions, in an ttemnt to add to the present knowledge of their st mucture.

samplea of Swedish 1ron $0.08 \%$ carbon, conteining Neumann bands, woro annealed at varlous temperatures in small tube furnace. Photomlerographs were made of oach samble, before and after annealing, wo that the actions of the leumann bands could bo observed.

There was no unlque oorreletion between Meumann bands and recrystallization, and the behavior of the Moumenn bends was similar to that of the grain boundaries. 
IHTKODUCTIOH 
Then subjected to mechanioal shook low carbon steel and relatively pure iron develop unlque change in grain structure. This change appears on a pollshed and - tched specimen In the form of otralght dark IInes or bands which are designated as "Noumann Bands". The exact nature of this change 1s unknown al though aeverel thoorles persiat. The ourpose of this inveatigation was to determine the effect of various annealing temperstures on existing Neumann bands in Swodish Iron apecimon. Informotion of this type, if auficlently complete and correlated, will eventuelly lead to an exact knowledge of the nature of this structural change. 
HISTORICAL 
Woumann bands are penerally belleved to be a form of crystal twin. $(10,2)$ The structure attributed to a twin 18, in genersl, the shifting of crystal section with reference to its original orientation. It is in other words a type of internal buckling. $(2,7)$ When the reorienteting has boen effocted, the section stands structurally as a mirror image to the original form and is symmetrical with respect to the original twinning plane.(7)

It 18 recognized that there are two types of twins, annealing twing and mechanical twing. The forwer are found In face-contered, cuble crystal lattices exclusively and the lettor in body-contered lattices. They are considered to be of a milar structural nature differing only in their space lattice relationships.(4,2) Annealing twins are formed by annea?ine a cold worked spectmen while mechanical twins se formed by cold defomation lone.(10)

Neumann bands are held to be elther mochanical twins $(4, z)$ or atructural change resulting from localized deformation brought about by rapid application of heavy stress. Roserhain and MeMinn(10) belleve the letter theory. They further meintain that Meumenn bands are sections through lamellae or thin plates and not of the nature of thin rods. Neumann bends are definitely en indication of strain in the motal, and as this internal buckling extends through the whole grein, they cen not be removed by re- 
polishing and rootching.(10) When a waterial is in such a state of strain annealing may be expected to produce recrystallisation of the grains. This recrystallization may be followed by grain growth, but it is doubtful whether an unstralned metal or metal in the cast state will oxhiblt these phonomene. $(11,9,8)$ 
PHEOKET ICAL 
Since Neumann bands are kmown to be an Indication of atrain, it is probable that the grains showing thew heve been more sererely strained then adjacent grains which havo no Ioumsnn bands. Also since the internal buckling which forms Heumann bande wes caused by this serere stress, It is logical to believe that the adjecent grains, free from Neumann handa, are in a stato of internal stresa greater than that of the buokled greins, since they have made no rearrangemant to relleve their atress. Stress relier ray have taken place in these unamked greins by alip banda which would not he vialbie becauae the polishing oberation nemoved them.(10) If this were true there would probably be no great atress afferentiation of the greins. Asauming, however, that the adjacent greins are In a tate of internel streas greater than the unriked greina, they would be expected to racrystellize or grow before the greins with Neumenn bends, for it is known that the groater the previous deformation of a metal the lower w111 be 1 ts recryatallization temperature. $(11,8)$

Recryatelileation upon annealing relieves the intemel stresses in the motal and tends to remove the distortion caused by mechanical deformation with the formation of new equi-axec greins.(3) The dimensions of these new grains are affected by the following factors; (1) amount of cold deformation, (2) size of distorted grains, (3) temperature 
at which deformation was produced, (4) a nnealing temperature, (5) length of time at annealing temperature and (6) the rate of cooling from annealing temperature. $(10,8)$

For most iron and steel there is a mumum recrystalliation tamperature, below which grain growth w1ll not teke ploce. This tomperaturo is the fr-l line in the Iron-iron carion equilibrium diagram(see $11 g .1$ ). However Stesd showed that there was a range of low carbon ateel, 0.04 to 0.12 o carbon, which recrystallized below this Ar-1 IIne and as Iow as 450 degreos Centigrade. He elso showed thet for each annosiling temperature in this range there was a definate critical strein vilue which would producs an abnormaly large grain size in the specimon. $(1,11,12,6)$ since the swodish iron used in this investigation conteined $0.08 \%$ carbon 1t should havo a mimum recrystallization tomporature somewhere between 450 degrees $c$ and the upper critleal line at 900 degreas $C$. At some temperature in thig range it might show abnormal grain sire.

Rosenhain (11) atates that the recryatallization of streined ferrite might be explained on the assumption that straining results in the production of amorphous cement or nucle1, which recrystalize on heating below the criticel ranfe. (11) If this be true, grain growth would be exposted to start at Heumann bands since thoir buckling 
action oroduces interfaces aimilar to a grain boundary. It 18 also known that recrystallization way otart inside a grain from muclel or fragments formed by cold strain, which might not be seen under the microscope. $(5,8)$ 


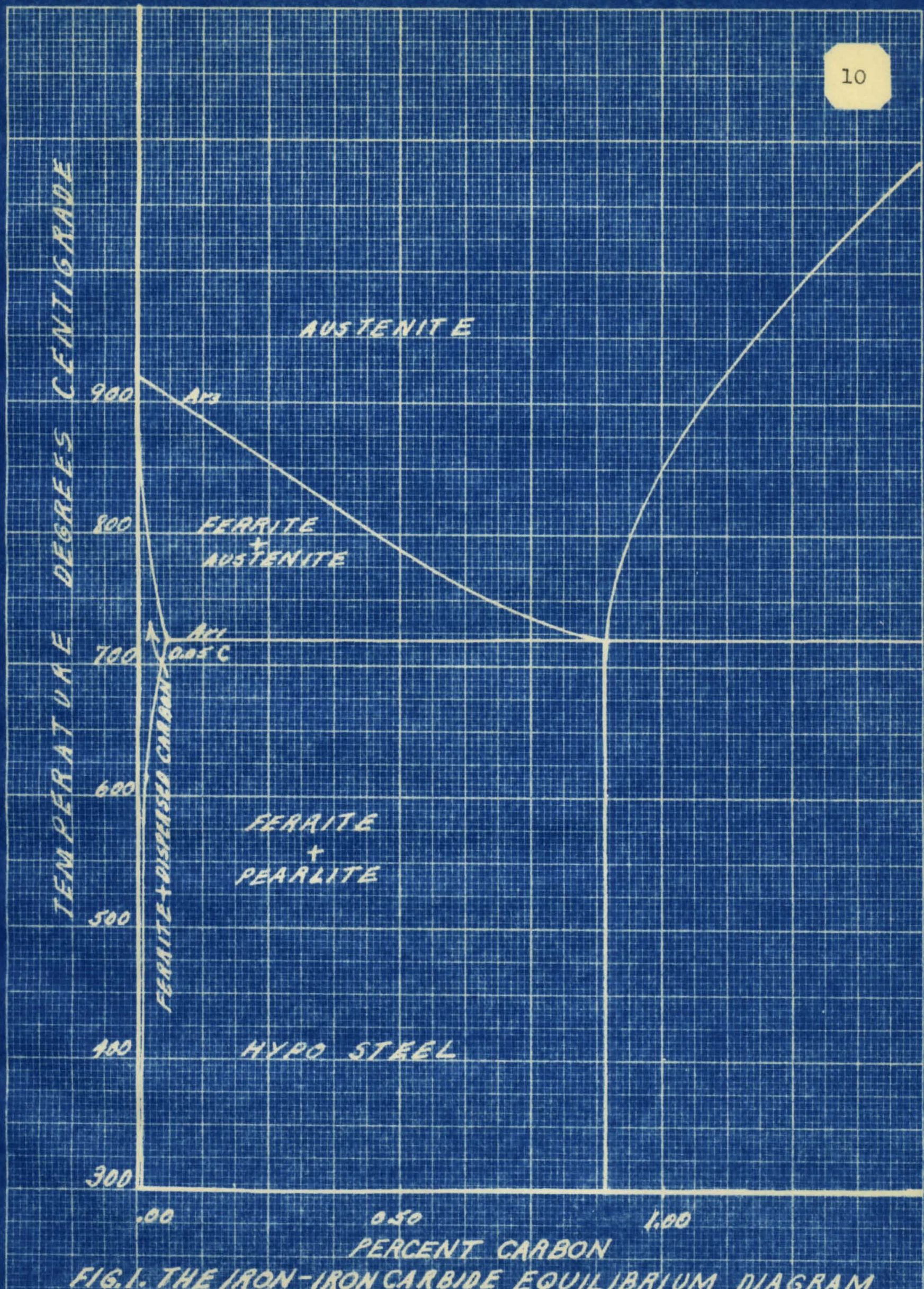


11

A PPARATUS 
A smell tube rurnace was constructed for annealing the samples of iron. The furnace had a heating element of Chromel C wire wound around a zirconia combustion tube. This wes sot in cylindrical sholl and the anmulus pecked with k1eselguhr. The meximum temperature for the furnace wes 1000 degrees $C$ on a 110 volt elreult, and the temperature wes controlied by an adjutablo rheostat.

The ends of the combustion tube were necired down, one end piece being detachable with a tight fitting rubber sloeve a connector. Rubber tubing connected the heating tube to a tank of hydrogen so that atrean of reducing gas could be circulated over the annealing spocimen.

A Chromel-Alumel themocouple wa la1d lengthwise in the combuation tube. The cold end, which protruded from one end of the tube, was sealed to the neck of the tube with perafín to prevent escape of the hydrogen gas. The junction was at the center of the tube where the sample would be placed. The EMFs of this the mocouple were read on a sandard Leeds and Northrupp portable potentioweter. Photomlcrogrephs of specimens were taken with a Le1tz Micro Metallograph "MM-I", 100 diemeters magnif1cetion, using a $23 \mathrm{~mm}$. objective and a $6 x$ Porlplan ocular. A camera bellows extension at $41 \mathrm{~cm}$. was used. Illumination was by an A.C. arc light and a prian 1lluminator. The spec1- 
men stege was equipped with movable markers and a calibrated scale so that the apot nnder obeervation could be found agein if the sample wa removed from the atage. 
14

PROCBDURE 
The wetal specimens wore cut from a $\frac{1}{2}$ Inch bar of hot rolled Swedish Iron, $0.08 \%$ oarbon, and were about $\frac{1}{2}$ inch long.

The sudden impect stress, necessary for the formation of Neumann bands, was effected by means of hammer blows on each sample. The specimens were then ground, pol1shed according to standard metallogrephic practice, and etched in a 5 nital solution.

A sample was pleced on the stage of the micromotallograph and a sot found whioh was sultable for further treatment and examination. All scale and holder notations were recorded for further Identifiestion procedures, and a photomierograph was made.

The specinen was next pleced in the center of the furnace and a slow stream from oylinder of compressed hydrogen pessed through the anneeling tube. The hydrogen tended to provent oxidation of the polished surface of the sample at the annealing temperature. The furnace was heated to the annealing temperature, and maintalned there for the correct perlod of time by means of the adfustable rheostat. When the perlod of annealing had explred the furnece was shut off and allowed to cool. A tempereture of epproximetely 150 cagrees $C$ wes reached after 4 or 5 hours cooling. The hydrogen was then shut off and the ends of the 
annealing tube sealed to prevent the entrance of oxygen. After further cooling to room temperature the ample wes removed.

The majority of the pecimens developed a thin, blue oxidie coet while in the furnace. This cont appeared to outline now and larger grains overlying the original grain structure. A photom1crograph was taken of the pot previousiy photographed so that the oxide grain outline could be compered with the new grains brought out by repolishing and reotching. This photomicrograph was opecifically for the purpose of correlating inftial and finel structures at the same sot.

The sample was then repolished, reotched, and the same spot reinspected. The new grain formation, in wost of the samples, conformed to the outlines of the oxide cott. A photomlorograph was taken completing the serles for that semple.

In the case of some secimens, the oxide coat developea boyond the point of grain visibility and a reduction had to be accomplished. This was done with a dilute, acid,stanous chloride mixture and the sample was then handled aimilarly to those described. 
DATA AND RBSULTS 
Figure 2 (page 19) is a photomicrographic series of a specimen annesled 1 hour at 950 degrees $C$.

The original grain gize in this aample veries through wide limits as shown in plate $\mathbb{A}$. The spot was on the edge of the spocimen and this rariation was probably due to the hot rolling process.

The three perallel Noumann bands at the bottom of plate A can be raintly seen through the oxide cost, in plate B. However there is no trace of them in plate C. The single band in the upper central portion of plate $A$ can be traced in plate $B$ ond 1 t lao has diaappeared in plete $C$. The bolishing scratches, which can herdly be seen In plate A, are brought out sharply in plate $B$ by the anneal and even more so in plate $C$ by the 11ght repolish and reetch.

The oxide cost in plate $B$ has formed in the shape of the new grains in plate $C$ as can be seen by compering the two. The grain formation in the lower right hend cornors of the two plates and the polishing scratches are the best identification marks.

The specimen shown in Figure 3 page 20) was also annesled 1 hour at 950 degrees $C$.

In this series of photomicrographs the sample markers were not used, and after the specimen was repolishod and reetched, the previously observed sot could not be 


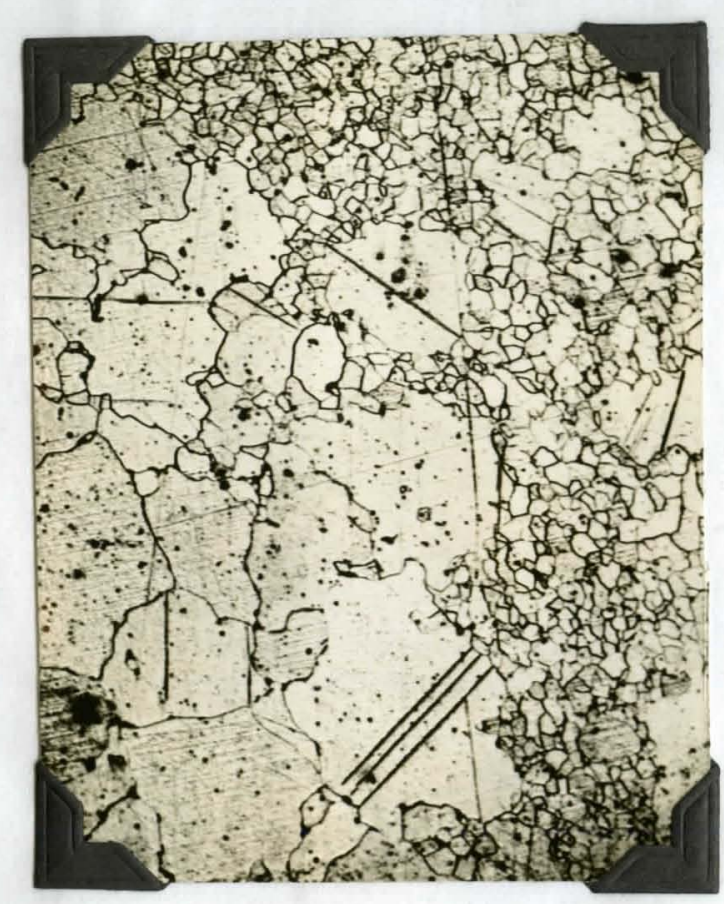

Plate A. Before anneal

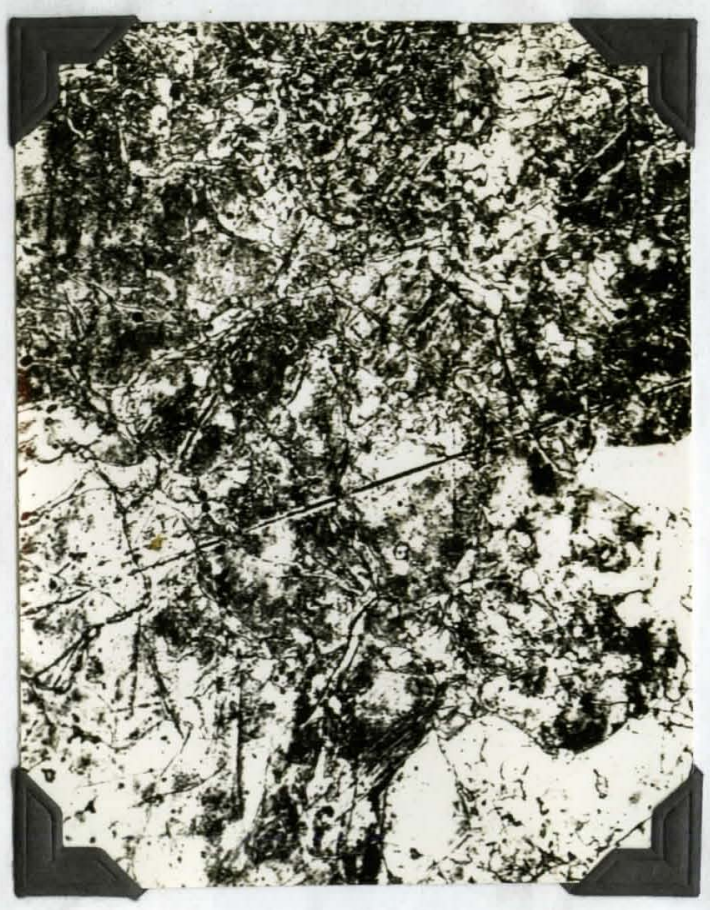

Plate B. After annealing for 1 hour

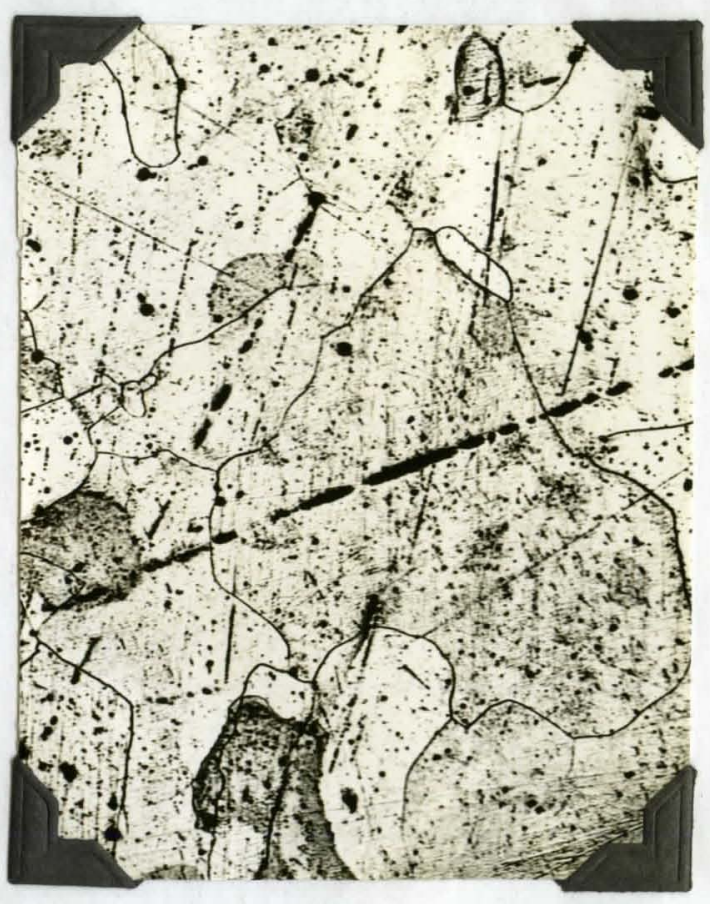

Plate C. Annealed specimen repolished and reetched

F1gure 2. Effect of Anneal at 950 degrees $\mathrm{C}, 100 \mathrm{x}$. 


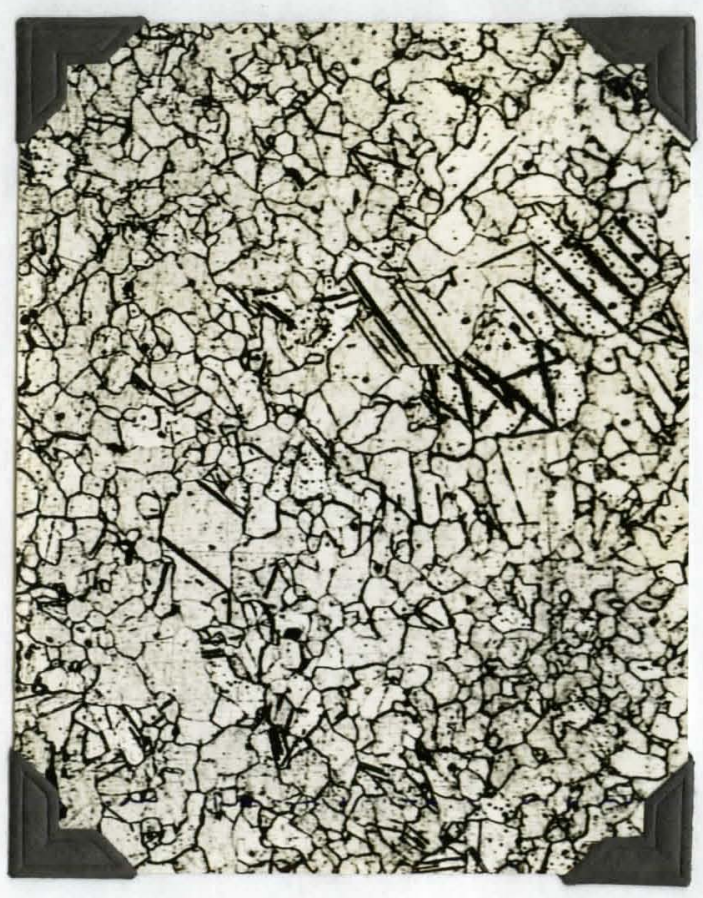

Plate A. Before anneal

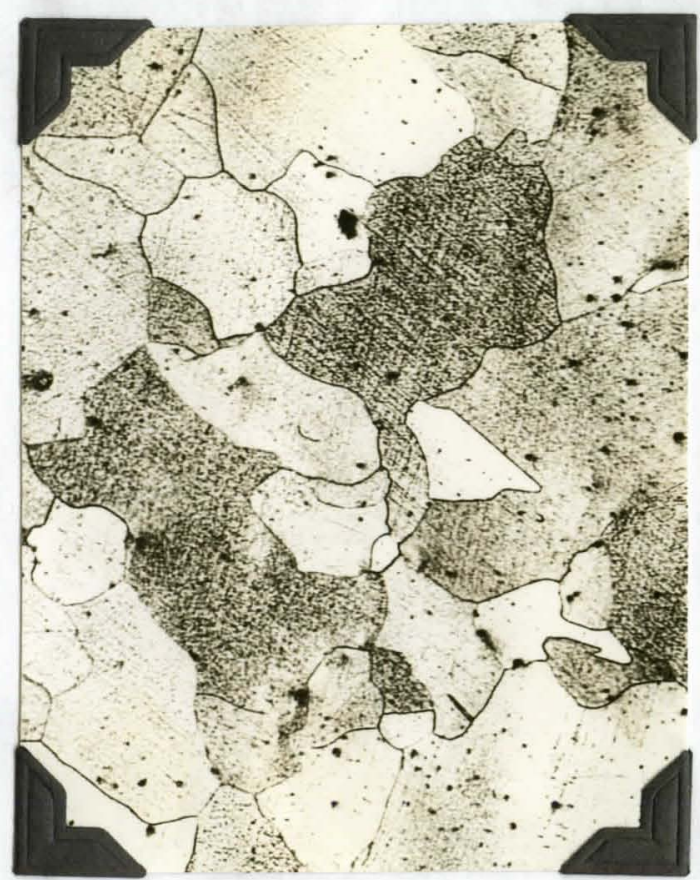

Plate C. Annealed specimen repolished and reetched

Figure 3. Bffect of Anneal at 950 degrees $C, 100 \mathrm{x}$. 
found. Plate C, therefore, merely shows the average size of the new grains.

The oxide coat was so dark after the anneal that a photomlcrograph could not be taken.

This anneal was above the upper critical line and the geries shows definite grain growth.A close examination of the entire specimen felled to show a single Neumann band, Indicating cowplate romoval by 950 degroes $c$ anneal al though the original greins were not followed in the photomierographic seriss.

$$
\text { Figuro 4 (page 22) } 1 \text { a a serles of a sample an- }
$$

nealed 1 hour at 850 dogrees $C$. The position of the Neumenn bands in this series can be followed, and it is soen that there is no trace of them in plate $C$. A comparison of plates and $C$ indicates that in some $28 \mathrm{ses}$ the new grains have formed directly acrosg the Neumenn bands. The bends in the upper right corner show this very well.

A comparieon of pletes $A$ and $C$ also indicates the roversal of relative gra in a1zes, 1.0. the area of fine graing has become that of large grains and vice verga. Figure 5 (page 23) is another series of a sample ennesled 1 hour at 850 degress $\mathrm{C}$.

The Neumann bends in this serles can be followed from nlate A to nlete $B$, but plate $C$ shows no trece of them. 


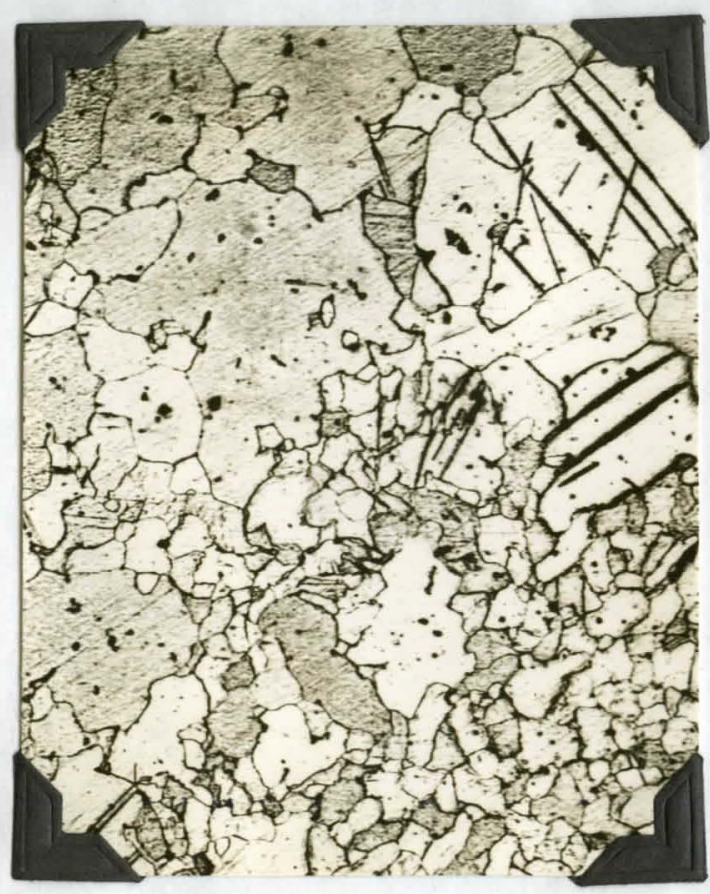

Plate A. Before anneal

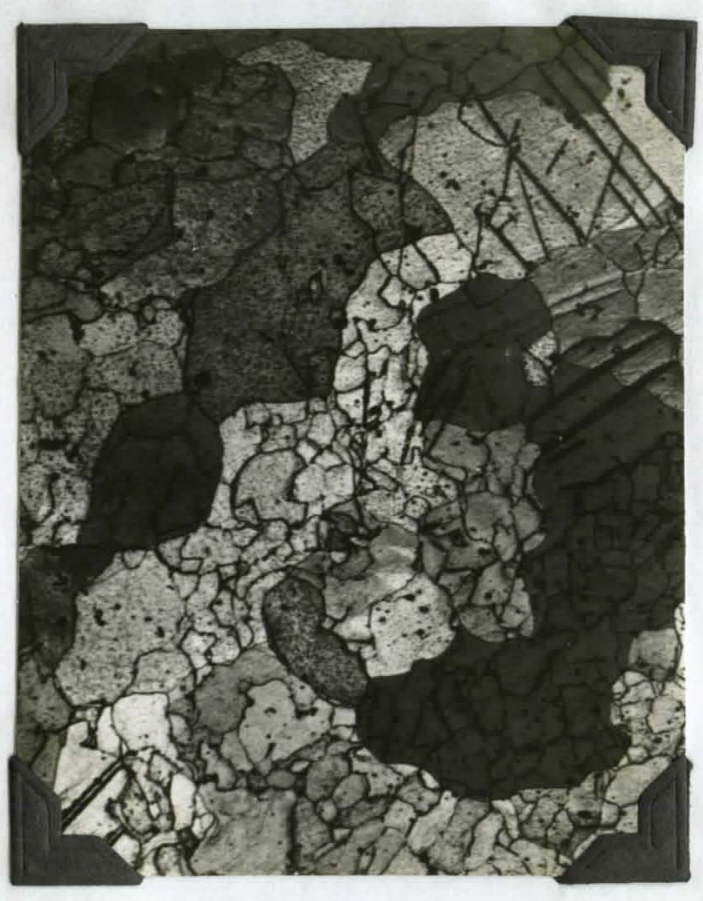

Plate B. After annealing for 1 hour

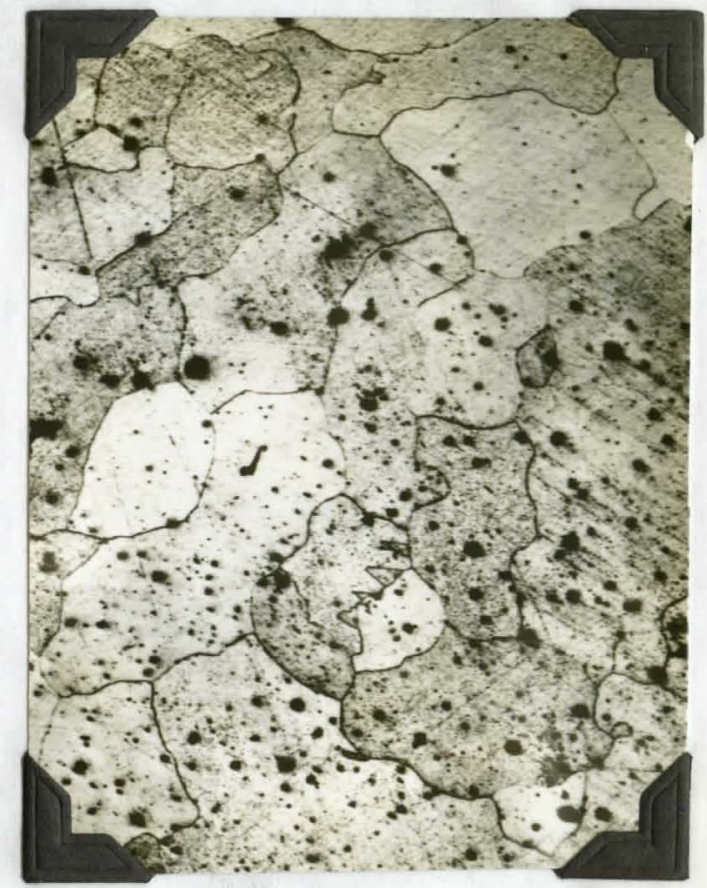

Plate C. Annesled specimen repolished and reetched

Figure 4. Effect of Anneal at 850 degrees C, $100 \mathrm{x}$. 


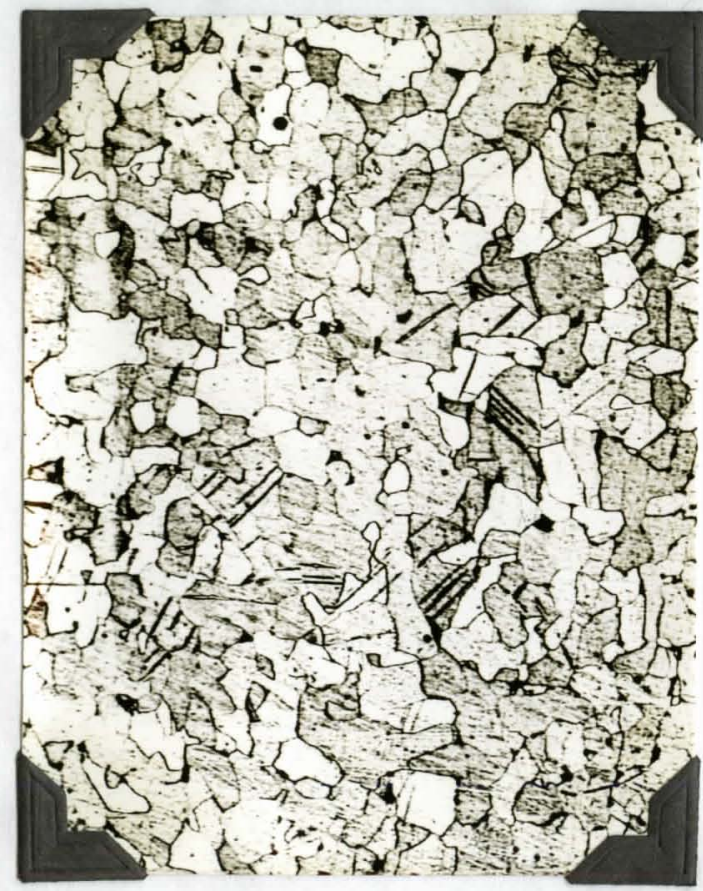

Plate A. Berore anneal

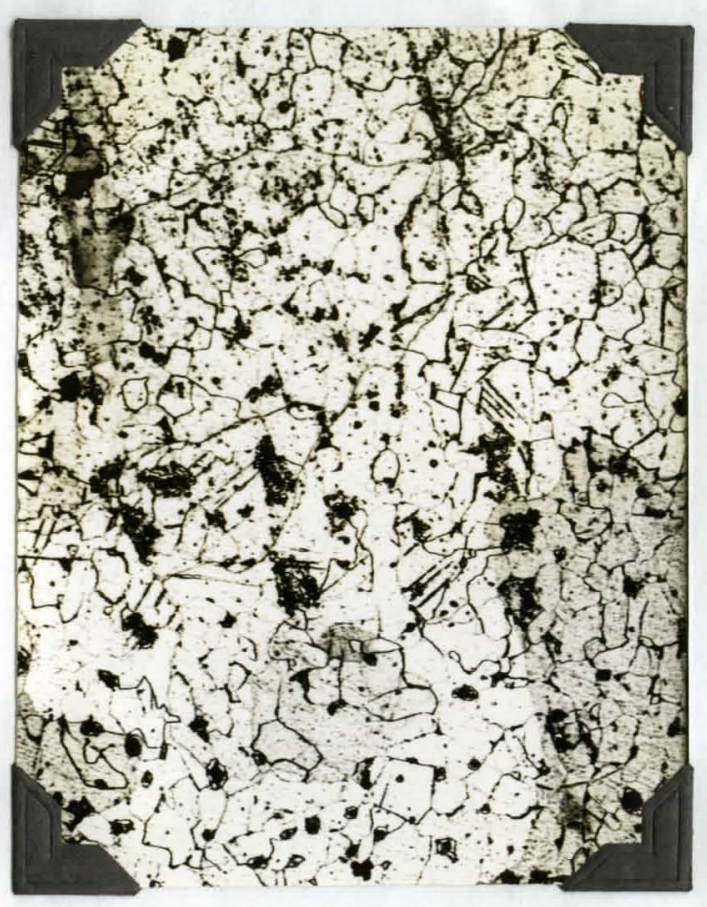

Plate B. After Annealing

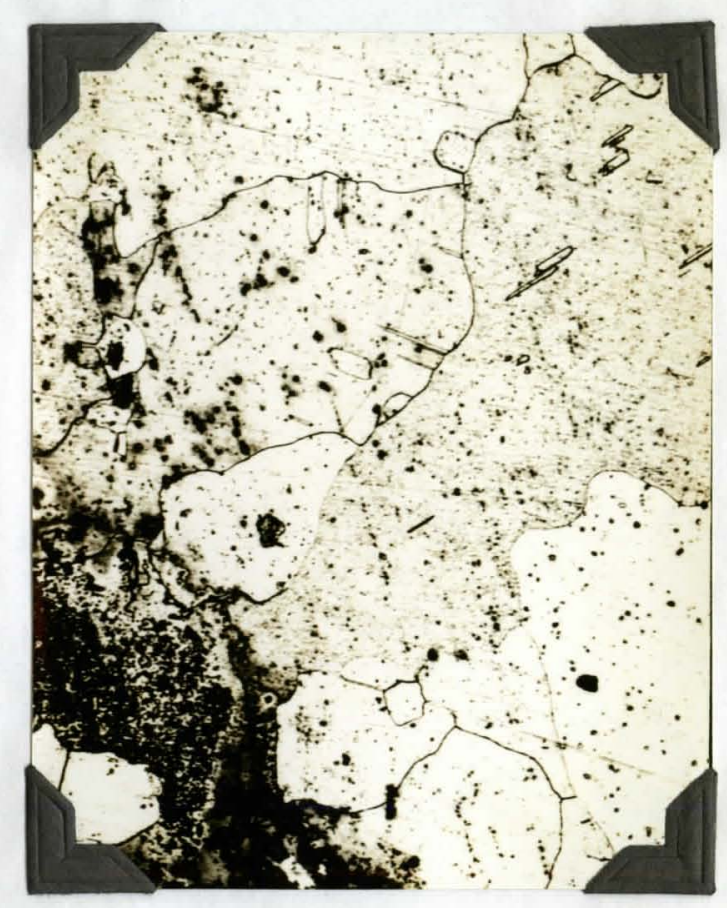

Plate C. Annealed specimen repollshed and re- tched

Figure 5. Effect of Anneal at 850 degrees C, $100 \mathrm{x}$. 
The large grein in the upper right corner hes an orlentation which sppeara to have no relation to the Neumann bands which were absorbed by 1 t.

The average intigl grein size of this series was finer than thet of F1g. 3, and the final grains are auch larger. This condition, however, has no bearing on this spocific investigetion.

The oxide grain outlines in plate B ape good roproductions of the final grains in plate $C$.

F1gire 6 (page 25) shows the effect of a 1 hour snnes 750 degraas $C$.

The Neumann bands in this series gro grouped in the center section of the sample, indicating that this portion recolvad the greateat atress. Plate 0 indicetes comploto effacement of the Mourann bands.

The grain alze in plate $C 1.8$ obnoraally lerge, and it is 11kely that thls degree of atrain produced germination at the 750 degrees $C$ annealing temperature.

The abnormel grains have followed the oxide outIIne, which can be seen by compering the upper edge and lower right corner of plate $B$ with the corresponding spots in olate $\mathrm{C}$.

The ample shown in Figure 7 (pege 26) was ennealed 1 hour at 650 degrees $c$. 


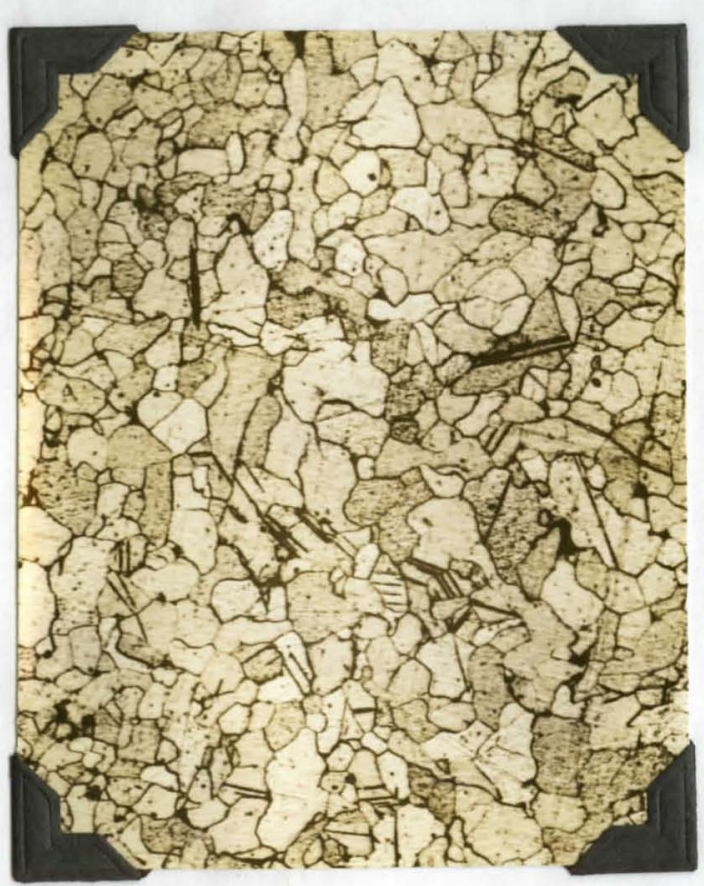

Plate A. Before anneal

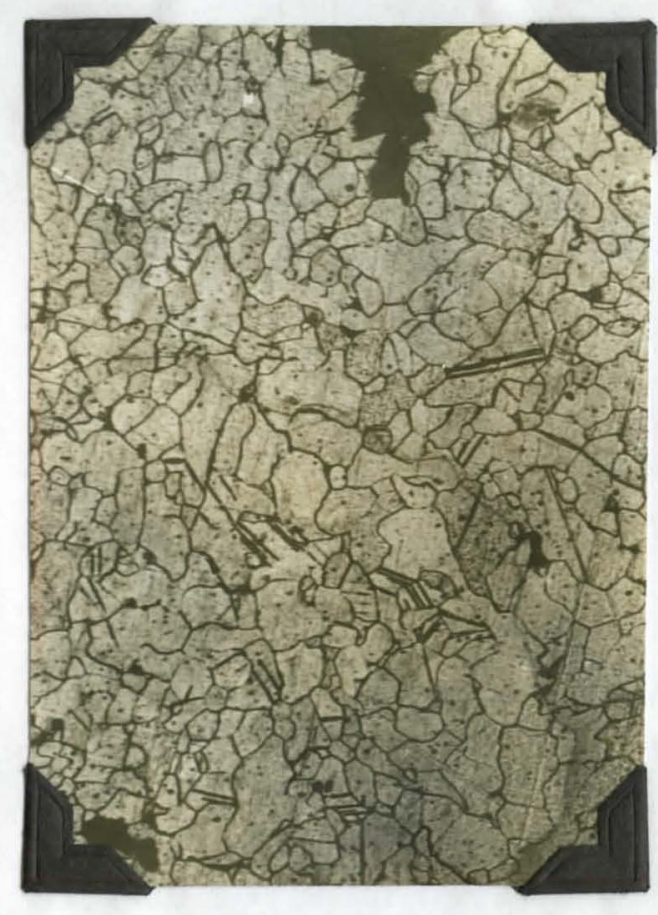

Plate B. After amealing

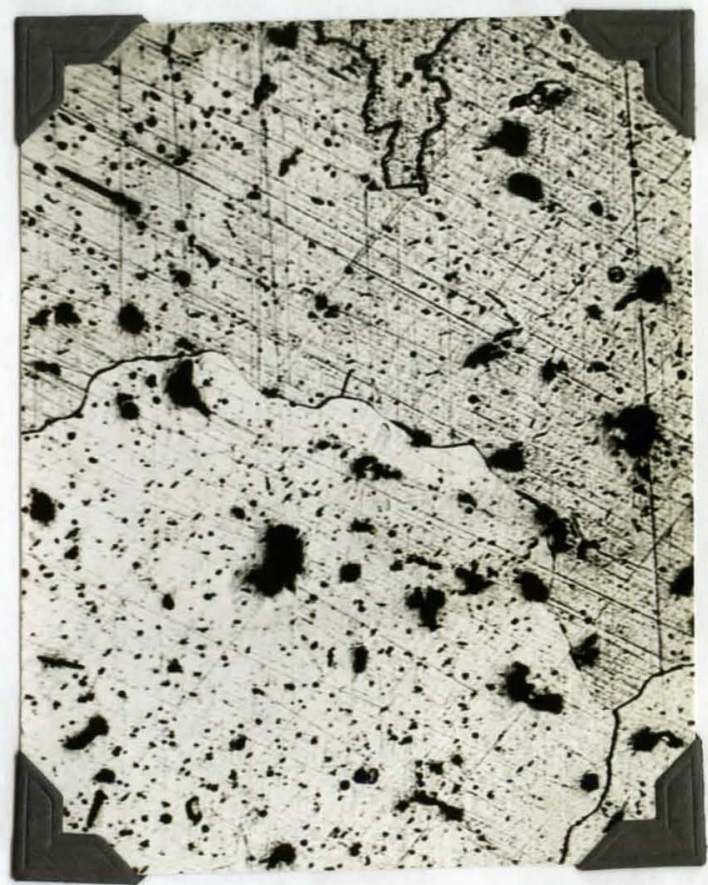

Plate C. Annealed specinen repolished and reetched

Figure 6. Bffect of Anneal at 750 degrees $C, 100 \mathrm{x}$. 


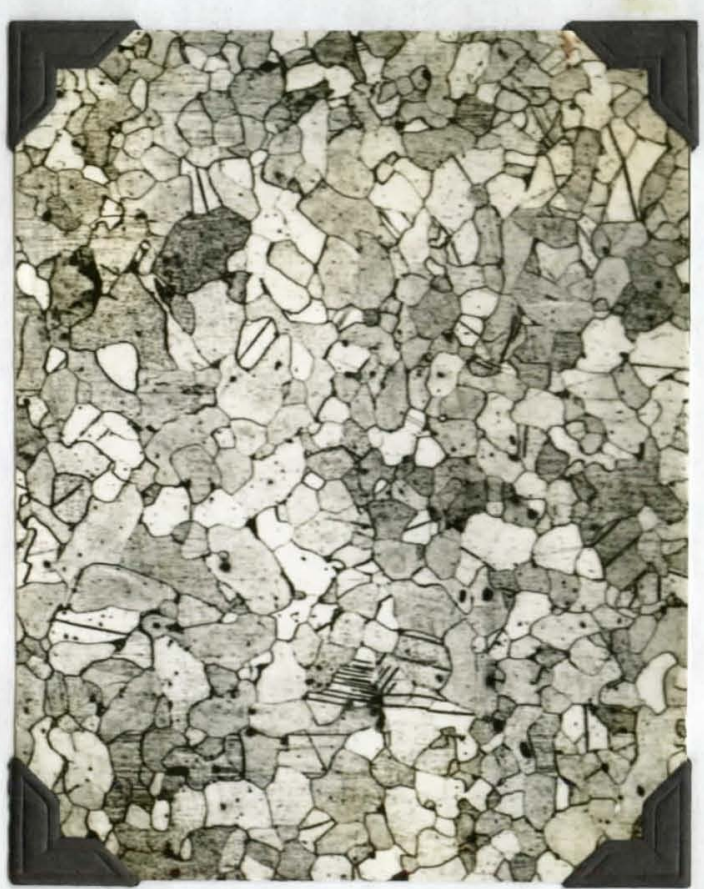

Plate A. Before anneal

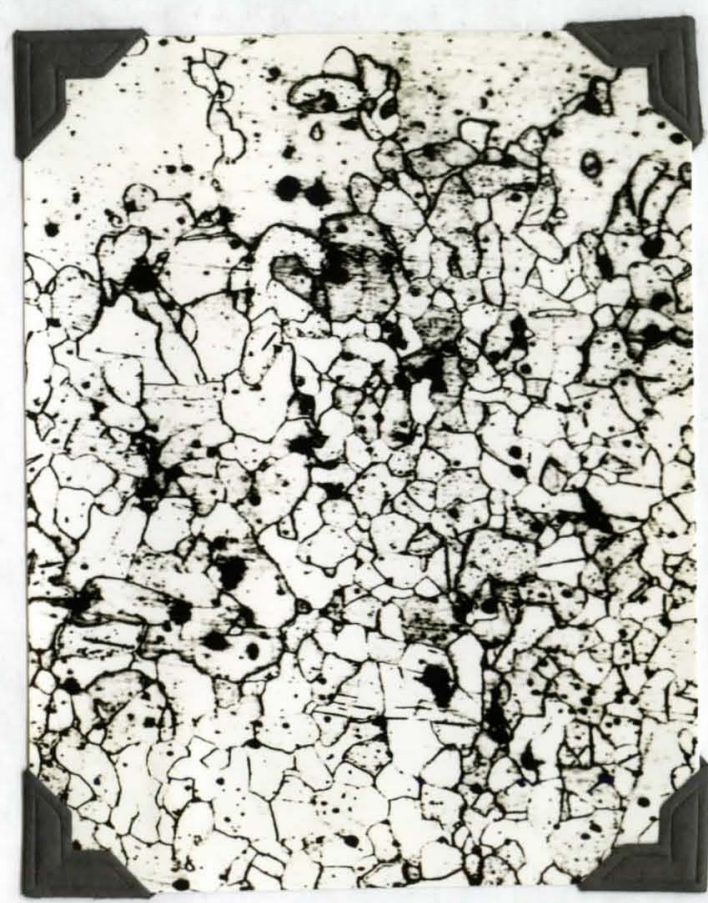

Plate C.Annealed specimen repolished and reetched

Bigure 7. Efrect of 1 hour Anneal at 650 degrees $0,100 x$. 
Annealing bas not wholly removed the Noumann bands in this seriea. Most of the Neumann bands in the central portion of plate A extend from one grain boundary to the other, while in plate $C$ they have been shortened and no longer reach to the boundaries. Some fow scattered bands have been completely removed.

Th1s 650 degrees $C$ annealing temperature is apparently just high enough to start recrystallisetion. It is ovident thet the large grains at the upper edgo are growing by fooding on the smalier ones. The Heumann in the upper right corner of plate $A$ is being absorbed by the new large gra in in that corner. The original cryatal which hold this bend anders to be partialif dissolved into the large grain. This section was a longitudinal section of the bar. The oxide coat after annealing was very dense, and it could not be properly thinned down with the stannous chloride solution.

Figure 8 (page 28) represents the offect of a 3 hour anneal t 650 degrees $C$ on a specimen. The Neumann bands in this series are ontirely removed by the annealing, and they appear to have had no effect on the final grain atructure. The oxide grain outline in plate $B$ is poor, but the sharp pointed grain outline protruding from the right 


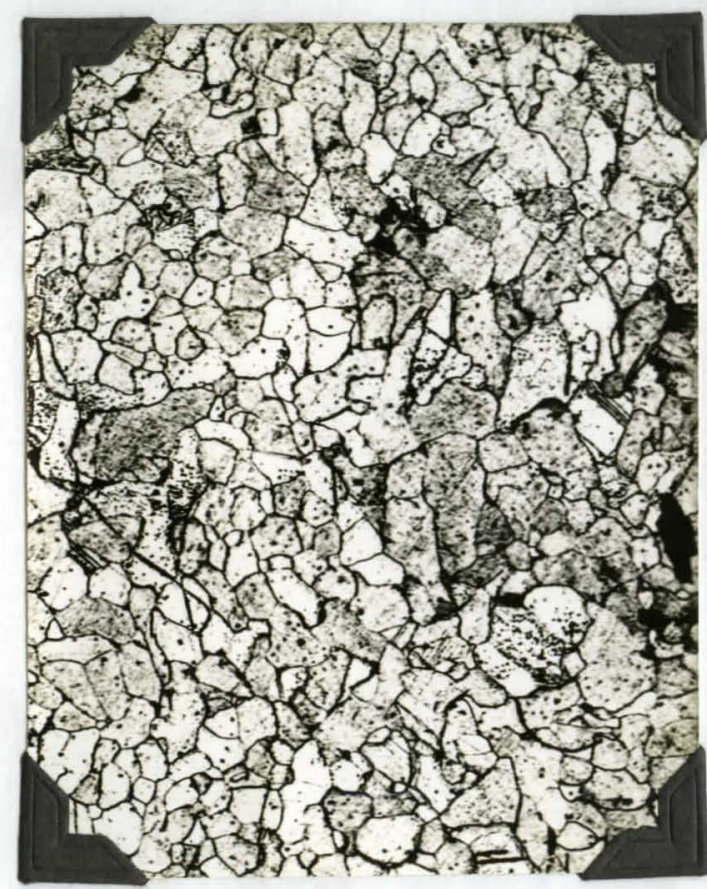

Plate A. Before anneal

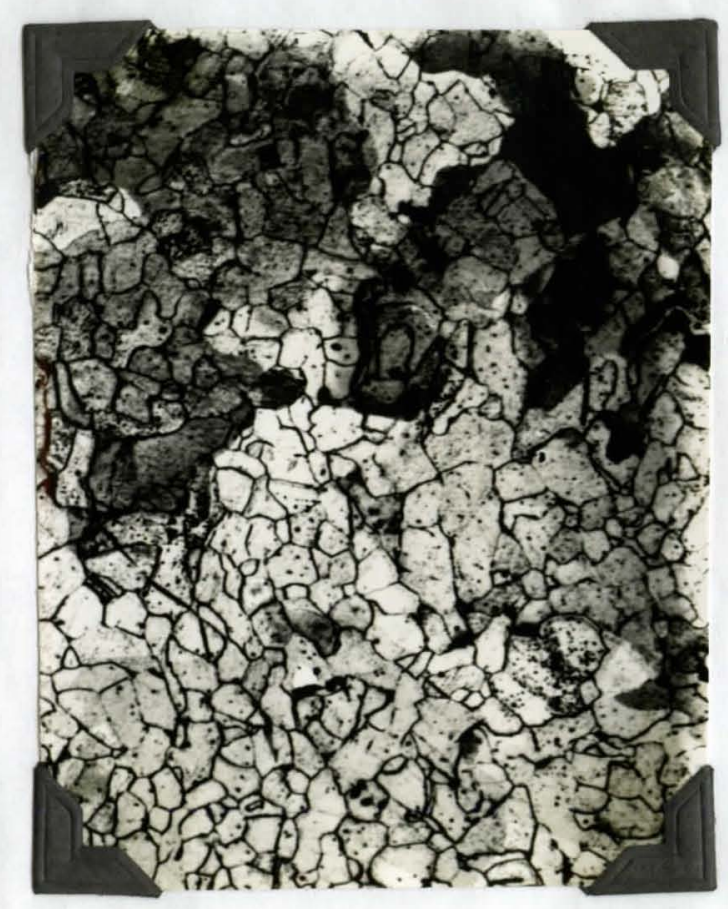

Plate B. After annealing

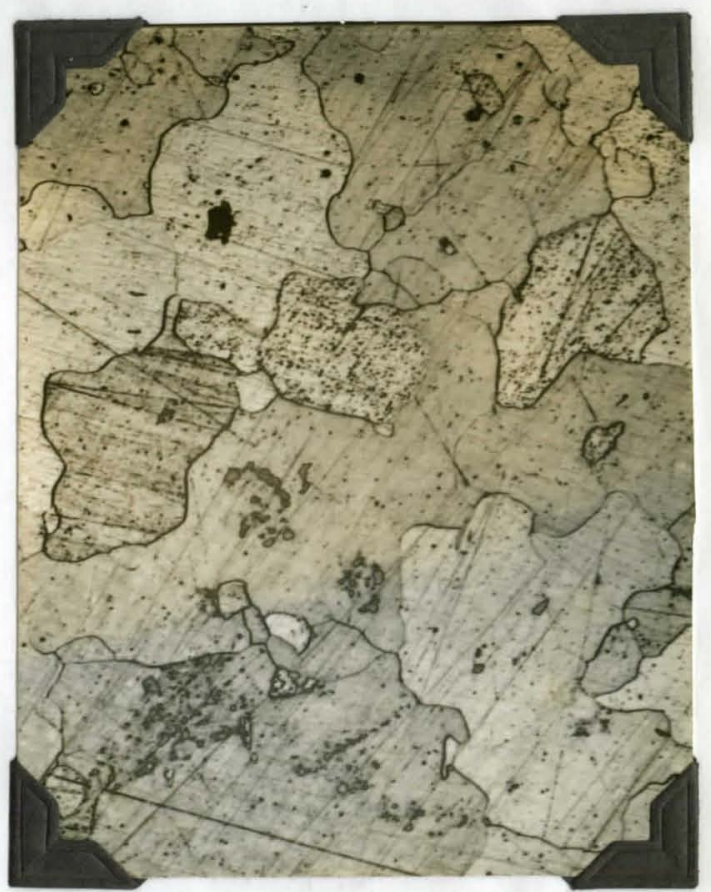

Plate C. Annealed specimen repolished and reetched

B1gure 8 Effect of Anneal at 650 degrees C, $100 \mathrm{x}$. 
edge of plete B, about three fourthe of the way from the top of the plate, can be seen as a grain in the agmo position on plate $C$. The reletionship between oxide and final grein can elso be seen in the upper right corner.

Although this anneal was the same temperature as thet of $\mathrm{Fg} .6$, the longer period of time enabled complete recrystelisation and grein growth to take place in this ser1es.

P1gare 9 (pago 30 ) 18 a photomicrographic series of apecimen amnealed 3 houre at 550 degrees $C$.

The Neumann bands in this eeries were not removed although some of thea seem to be shortened and thinned. Plate B shows definite signe that grain growth 18 beginning, but the greing with the Neumann bends are not in eny way unique. 


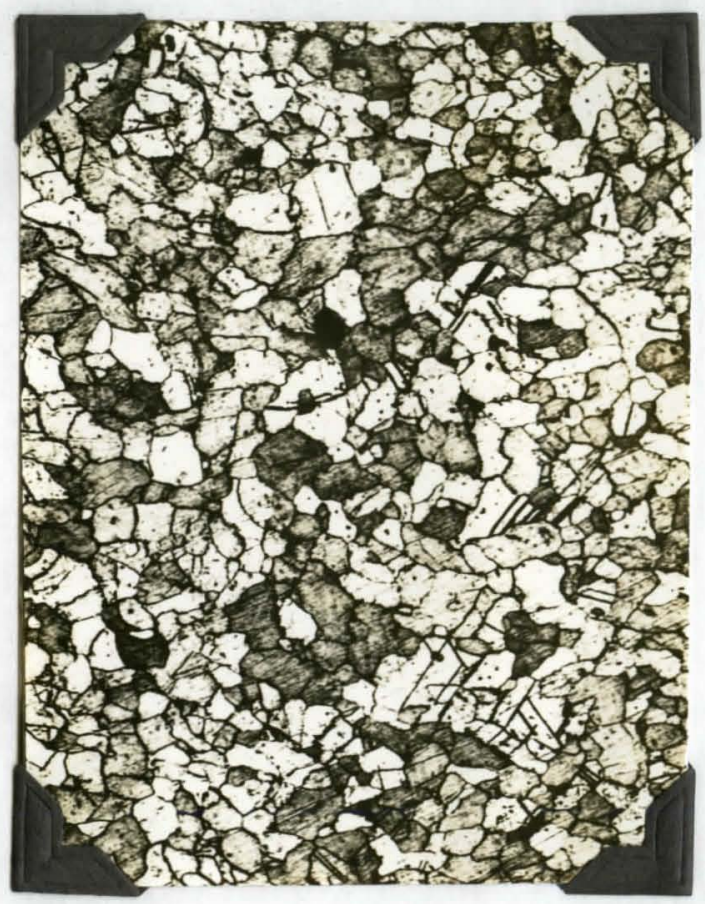

Plate A. Before anneal

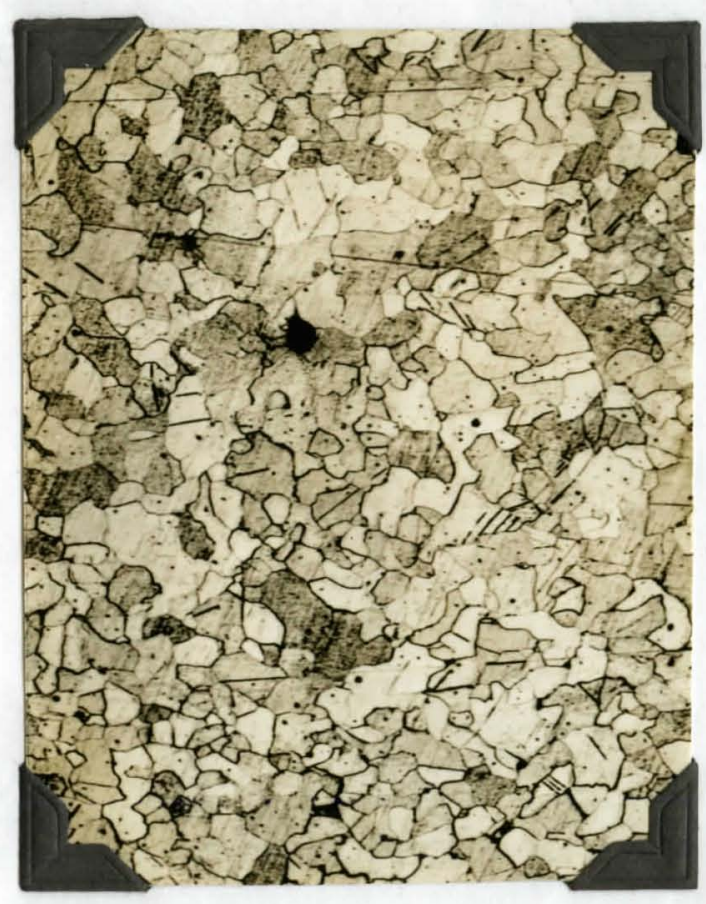

Plate C. Annealed specimen repolished and $r e-$ etched

Figure 9. Bffect of 3 hour Anneal at 550 degrees C, $100 x$. 
31

SUMMARY 
The results of this investigation indicate that Neumann bands are completely removed above the oritical temperature. 700 denrees C. Below this temperature they tend to peraist and their eotion 1s very similar to thet of the original grain bounder10s. Whon greins containing Heumann bands are belng absorbed, the bands become fainter and thinner, finally diaepearing completely.

The orientation of the Hewmenn bands do not affect the orientation of the growing grains, and there 18 no difference in the manner of absorbtion of the marked or umaerked grains. In some casea the new grain boundaries cut the exact IInes where the Neumann bands had been orfina11y. 


\section{3}

A P PGIDIX 
SAMPLB DATA SHEET

\section{Sample 2}

section Trapecuere

Annea 1 the at $20^{\circ} \mathrm{C}$

\section{Camera settings}

Objective $\frac{23 \text { men }}{\text { Ocular }}$
Illuminator $\frac{6 \times \text { Periplan }}{\text { Bellows }}$

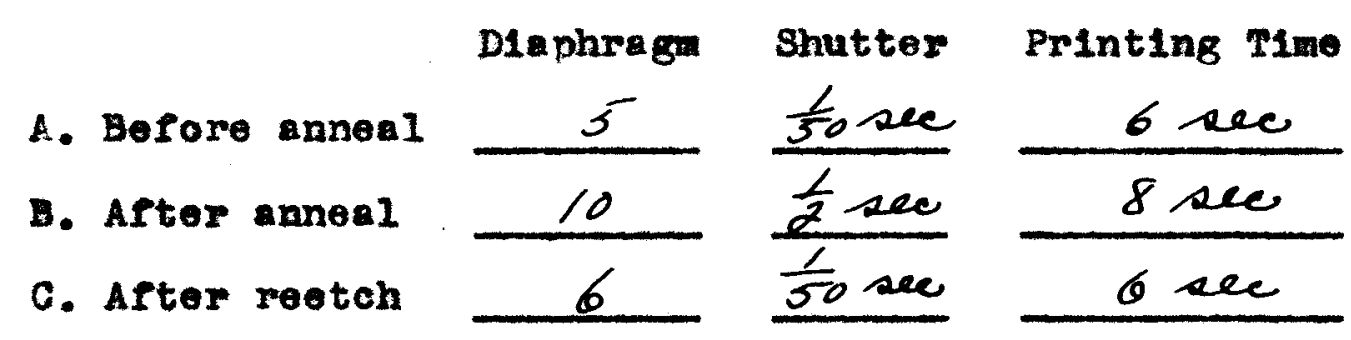

Plates- Wratten and Fainwright Metallographic Dry Plates

Plate Developer - D-70

Print Developer - D-72

Pigare Z 
1. Bullens and Battollo - "Steel and Its Heat Treatment" Fourth Edition, Vol. 1.pp. 121 John Wlley and Sons, Ino. Now York 1938

2. Heyer, Robert - "Ingineering Physical Metellurgy" F1rst Rdit10n, pps. 6, 153 D.Van Mostrand Co.,Ino. How York 1939 .

3. 1b1d. pp. 237

4. Jeffries and Archer - "The Seience of Metels" Firat Bdition, pp. 51. MoGraw H111 Book Co. How York 1924

5. Ibid. nn. 86

6. 1b1d. pp. 107

7. Liddel and Doan - "Principles of Metallography" Pirst Edition, pp. 402 MoGraw Hill Book Co. New York 1933

8. 1b1d. pp. $419-426$

9. Newton, Joseph - "An Introduction to Metellurgy" First Edition, pp. 20-31. John w1ley and Sons, Inc. New York 1938 .

10. Seuveur, Albert - "The Motallography and Heat Treatment of Iron and Stee1" Fourth Ed1tion, ppe. 25-29. Mcaraw H111 Book Co. New York 1935.

11.1b1d. pps. 285-292.

12.8toughton and Butts - "Ingineering Metallurgy" Third Bdit1on, pps. 212-215. McGrew H111 Book Co. Now York 1938

13. Woldman - "Physical Motallurg" pps. 57-73. John wiley and Sons, Ino. New York 1930 
VITA

\section{Alex B. Davidion}

Alex B. Davidson, the son of Harold B. Davidson and V1olet S. Devideon, was born in Hemphis, Tennessee, on April 17, 1917. At the age of three he moved to Loulsville, Kentucky, and has lived there from thet time. Mr. Devidson attended the Loulaville public schools and finished his secondary school education in Louleville Male High Sehool, 1935. He attended the Speed solentifie School of the UnIvera1ty of Loulaville from 1935-1939 rocelving a degree of Bachelor of Chenical Englneering. His thesis was "The Tantalum Electrode for pH Heasurements." During his college career Mr. Davidaon was activo In extra curricular activitios culminating in the captaincy of the University of Louleville football aquad of 1938. 